\title{
INTERNATIONAL FINANCIAL REPORTING STANDARDS
} AS THE BASIS OF ACCOUNTING DEVELOPMENT IN THE CONDITIONS OF GLOBALIZATION OF THE ECONOMY

\author{
N. Potryvaieva, Doctor of Economics Sciences, Professor \\ ORCID ID: 0000-0002-9781-6529 \\ O. Luhova, Candidate of Economic Sciences \\ ORCID ID: 0000-0003-4432-0295
}

N. Janovsjka, Higher Education Learners

Ju. Klochan, Higher Education Learners

Mykolayiv National Agrarian University

The article reveals the role of International Standards Financial Reporting of in the process of globalization of the world economy. The analysis of the preconditions and stages of the transition to the International Standards of Financial Reporting is presented. The results of application of international accounting standards are described, their advantages are formulated. The problems of Introduction of International Standards of Financial Reporting in the national accounting system of Ukraine are determined.

Key words: globalization of the economy, accounting, International Financial Reporting Standards, statements' users.

Statement of the problem. In the near future the development of civilization, including the field of economics, will take place under the influence of two qualitative complementary and interdependent processes: world globalization and information revolution and standardization of accounting rules.

The global economic space, which greatly affects the provision of accounting information to society, is characterized by institutional and legal factors like the participation of countries in international organizations, the unification of professional communities of different countries, the application of common rules in the formation of reporting.

Indeed, the globalization of the economy and the formation of an international accounting system in this content, do not give grounds to doubt the need to introduce a new strategy for accounting development. Clive Booth, the Manager in Public Relations and Media of the Association of Chartered Certified Accountants (ACCA), notes that the decision of the European Union to transfer to international financial reporting standards (hereinafter referred to as IFRS) has become a turning point in the development of a global accounting system and unified standards. The author remarks: "It's extremely important not to return to regional norms which are difficult to reconcile" [1].

The current stage of the socio-economic development of Ukraine is closely linked to world globalization, the economic crisis, and is characterized by further strengthening of market relations, the strengthening of European integration processes and the transition to IFRS.

The development of international economic relations within the framework of globalization is one of the objective conditions for significant changes both in the Ukrainian system of accounting and reporting, and in accounting systems of almost all countries. Moreover, the reflection of modern international processes in national accounting systems is a complex, mostly unresolved problem.

The analysis of actual research shows that some domestic economists devoted their works to the study of issues related to the impact of economy globalization on the processes of standardization of accounting. They are S. Holova, V. Zhuk, H. Kireitseva, R. Kuzina, N. Maliuha, V. Palii, V. Parkhomenko, O. Petruk, V. Sopko and others. The foreign economists who dedicated their works to this problem are A. D. Britton, B. Lev, E. Jenkins, O. Nikolayeva, E. Richard, S. A. Dipiasia, R. J. Eccles.

R. Kuzina [2] states that the impact of globalization processes on the accounting system is obvious - in fact, accounting data is the information that has all the peculiarities inherent to information.

Recently, an increased interest and the discussions around the place of accounting in the management system, the development of accounting as a science, the adequacy of the reflection of

(C) N. Potryvaieva, O. Lugova, N. Janovsjka, Ju. Klochan, 2018 
operations and processes, objects of accounting have appeared. The trends of globalization in the field of economics concern the accounting and reporting system and set the task of solving international accounting problems. One of these solutions is the development and dissemination of IFRS.

The research [3] states that bringing national accounting and reporting systems in line with international standards is a way to internationalize and harmonize accounting, to improve the quality of accounting information and to trust it from different users.

In his research, S. Holov finds arguments in favor of the introduction of a global accounting system, noting that "... the goal of maximum convergence of national financial reporting standards with international ones at the moment is one of the most important objects" [4].

It should be noted that Ukraine made its strategic choice in favor of IFRS - orientation [5]. In his monograph [6] V. Zhuk observes that the conceptual basis of world-wide accounting development will be the convergence of international rules established by IFRS and US GAAP US principles into uniform world financial reporting standards (or the updating of IFRS). The theoretical basis for such a convergence can be the model of ensuring transparency of R.J. Eccles and S.A. Dipiasy company, which requires the development of World Financial Reporting Standards and, along with them, the formation of lower baselines - industry and corporate standards, which should solve most of the problems of IFRS. However, scientists don't devote sufficient attention to the consideration of the issues, connected to the influence of economy globalization on the harmonization of accounting.

The purpose of the article is to reveal the influence of globalization of the economy, to study issues related to the impact of globalization of the economy on the harmonization of accounting, to clarify the main problems of the transition of Ukrainian business entities to IFRS, the advantages and disadvantages of their application.

Basic material presentation. Globalization as a concept is often used in the last few decades in scientific and political literature and it is used in its meaning in each of the social scientific disciplines. However, globalization as a phenomenon has become the subject of serious scientific research in modern society. This category is used in economics, geography, international relations, technological sciences, philosophy, law and other spheres.

Speaking about the definition of the term "globalization", V. Peftiev and V. Chernovska define: "globalization is at the moment the highest phase of internationalization (integration) of economy and politics" [7]. They believe that globalization is characterized by the scale of financial transactions, the growth of international trade, the rapid flow of capital, and the activities of transnational corporations.

This stage of economic development is preceded by the following consolidated stages of the development of economic relations: 1) the development of productive forces, 2) international division of labor, 3) international economic cooperation (internationalization of production and capital), 4) international economic integration [8]. Thus, globalization of the economy is nothing more than a "regular" stage in the development of economic relations, due to the increasing interconnection and interdependence of the economies of particular countries and regions, which, in turn, gradually leads to their functioning as an integral system of economic domination of the world economy, which is a single market for goods, services, capital, labor and knowledge.

By decomposing the globalization process of the world economy, one can speak of its components as: 1) internationalization of production, 2) globalization of productive forces, 3 ) increase of the scale of international labor migration, 4) deepening of internationalization of exchange, 5) deepening of internationalization of capital, 6) growth internationalization of the impact of production and consumption on the environment, 7) the formation of global infrastructure $[9,10]$.

The emergence of global financial markets at the turn of the 1970's for developed countries and in the 1990 's for emerging market economies has led to the fact that national accounting systems were not all and not always able to provide financial information in the angle required for participants in the international market. First of all, this was due to the fact that each state had its own experience, knowledge and traditions of accounting and reporting. In world accounting practice, there was a need for integration and harmonization of different accounting systems. According to B. Needles, H. Anderson, D. Caldwell: "Some problems arise because accounting has developed in different countries in different ways ... All this complicates the activities of companies abroad" [11].

In order to determine the influence of processes of globalization on accounting processes L. Stefanovich [12] highlights three types of accounting and reporting systems.

1. National system. Each country has its own national accounting and reporting system, which in the process of historical development is constantly being improved in line with the changes in the economy. Accounting systems have much in common with each other, but at the same time there 
are cardinal differences due not only to economic and political reasons, but also related to national and historical customs, traditions, business practices. The governments of states independently (or on the initiative of international financial institutions) decide on the necessity, the direction, the degree and the time of harmonization of the national accounting system with the international one.

2. The regional system provides for accounting and reporting based on the rules, principles and standards defined for states united in regional groups.

These countries are close geographically and historically, often lack linguistic barriers, traditionally and economically interconnected. The most developed regional group, formed in 1952, is the European Union (EU). The Council of Ministers of the EU and the European Parliament adopt the directives governing the formation of financial reporting in EU member states. In addition, a block has been formed on the American continent, which directly includes the United States, Canada, England, named North American Free Trade Agreement (NAFTA). Accounting and financial reporting in this group are carried out in accordance with the principles and standards of the AngloAmerican accounting system [13].

3. The international system involves accounting and financial reporting in accordance with generally accepted accounting and reporting principles and international financial reporting standards.

After considering three types of accounting and reporting systems (national, regional, international), we can make conclusions:

- these kinds of systems are equal in essence, as each of them performs the tasks set for it;

- national and regional systems of states can be agreed to the international system in case of generally recognized principles and IFRS application;

- the national and regional systems of countries are characterized by conservatism in comparison with the international system, which depends on "IFRS, which are repeatedly changed, updated and largely reflect experimental accounting practice" [14].

Globalization is associated with homogenization, that is, intrusion into the life and corporate management of common rules (standards).

The emergence of supranational accounting standards (IFRS) is due to the non-consistency of financial reporting, drawn up in accordance with different national regulations, the need for the transformation of national accounting in forms that meet the requirements of the world economic community. The goal of IFRS is to eliminate this drawback of accounting information, which makes it unsuitable or at least has significant limitations for making economic decisions.

Solving the problem of comparability of reporting financial information and, as a consequence, providing investors and loan providers with useful information for making economic decisions was proposed by the Council on International Financial Reporting Standards.

Let's consider the details of the application and stages of the development of IFRS in the world and Ukraine and analyze the effect of the application of IFRS in our country.

The prerequisites for the development and implementation of IFRS in the world were largely due to the economic crisis of 1929-1933. The collapse in world stock markets in 1929, which led to the long-term global economic crisis in industrialized countries and regions, identified the imperfection of the existing accounting system and financial reporting. Since the conceptual framework for compiling financial reporting in different countries and even at different enterprises in one country differed significantly, the information was unmatched for users and couldn't be used in economic relations. Such circumstance led to ambiguous and false conclusions about the financial position and the performance of the enterprises that compiled and filed reports.

In the early 1930 's, the United States began to develop a system of nationally accepted accounting standards (hereinafter GAAP) and reporting that were used by large companies represented on stock exchanges on their will. On the basis of these standards, the US GAAP system came to an end over time.

The Federal Commission on Securities now requires the use of GAAP by all major listed companies on US stock exchanges.

European countries have gone through the mandatory application of national plans of accounting on the model, developed by the famous Austrian accountant E. Schmallenbach, by all companies. In the period before the Second World War, all the needs of European countries in financing were met at the expense of domestic sources, the situation changed dramatically after the war. Special assistance programs for the reconstruction of destroyed countries have contributed to a significant increase in international capital markets. In order to account for the gross domestic product and other indicators of national economic statistics after World War II, the system of national accounts emerged from the plans of accounting of E. Shmallenbach. 
Nationally recognized accounting standards, developed in the United States, have spread to Mexico, Canada, England, Italy and other countries. GAAP in each of them had its own specifics, but provided everywhere some stability and unity of approaches to accounting and financial reporting, guaranteeing its comparability with the reporting of other national enterprises. This approach to accounting and compilation of financial statements has led to the fact that the authenticity and reliability of reporting information has increased and, as a consequence, the confidence in it by various users increased.

National GAAP were replacing by IFRS gradually, but inevitably and steadily. Although IFRS absorbed many "generally accepted accounting principles", they went further in developing standard norms to reflect on the financial statements of new phenomena in finance and the economy.

The development of IFRS began in the 1960's under the auspices of the United Nations Center for Transnational Corporations. In the early 1960s, the US President John Kennedy while speaking to the UN General Assembly drew the attention of the world community to the development of global economic relations based on transnational corporations. For a normal functioning of new relationships, a "universal language of business communication" is required. He called the accounting and financial reporting, accessible and understandable to all interested persons as such language.

The United Nations Transnational Corporations Center has begun work on IFRS. Later, in 1973, the London International Accounting Standards Committee (IFRS) was set up by the professional accounting organizations of several countries as an independent private sector body. The countries included were the USA, Canada, Australia, France, Ireland, the Netherlands, Mexico, the United Kingdom, Germany and Japan [3].

All professional organizations members of the International Federation of Accountants since 1983 became members of the IFRS Committee. The purpose of the IFRS Committee is to unify the accounting principles used by companies around the world while compiling financial statements. By its nature, the IFRS Committee is an independent private entity whose purpose is to develop common accounting principles that are used by commercial entities and other organizations around the world when compiling financial statements.

Until 1989, the Committee worked on the generalization of accounting practices in 10 countries. As a result, a document was issued in the form of a set of rules and explanations called "International Accounting Standards".

The period of formation of the IFRS in the modern form is considered to be 1989-1995. In these years, several more countries were joining up to 10 ones (Cyprus, Singapore, Malaysia). Another reason for the introduction of IFRS was the need to introduce a specific mechanism that would help to attract foreign investment. The versatility of the new standards and their transparency have both contributed to an increase in the flow of foreign capital. The versatility of the new standards and their transparency have both contributed to an increase in the flow of foreign capital.

1995-2000 was the period of the emergence of key international standards. It started with close cooperation with reputable international organizations. European countries implemented the IFRS at the legislative level, although national standards continued to play a primary role.

Since 2000, the convergence of international and national standards has begun, which has led to the globalization of financial standards. The reform of the Committee on International Standards has taken place: its functions have been passed to the Council (IASB), and the Council has become the part of the IFAS Committee Fund (IASCF) [15].

The question of the introduction of international standards in domestic accounting practice has been in Ukraine since the declaration of independence and the need to build its own accounting system. At the regulatory level, the transition to international standards was approved in 1998 with the adoption of the Program for the reform of the accounting system with the application of international standards, the main tasks of which were:

- creation of a system of national accounting regulations (standards) (Ukrainian Accounting standards), which could provide the necessary information to users, especially investors;

- ensuring communication of accounting reform with the main tendencies of harmonization of standards at the international level and the state of economic-legal environment and market relations in Ukraine;

- provision of methodical assistance in the implementation and use of the reformed accounting system [16].

In 1999, the Law of Ukraine "On Accounting and Financial Reporting in Ukraine" [17] was adopted, which defines the principles and methods of accounting and financial reporting that are not contrary to international standards. With the adoption of this state act, the stage of reforming the accounting methodology has begun; its static model has started to change dynamically. 
The Resolution of the Cabinet of Ministers of Ukraine of 24.10.2007 approved the Strategy for the Application of International Financial Reporting Standards in Ukraine [18], the main tasks of which are:

- creation of legislative and organizational prerequisites for the introduction of international standards in the compilation of financial statements by the economic entities;

- creation of favorable organizational and legal conditions for the application of international standards in the compilation of financial statements by the economic entities and submission of them in electronic form taking into account international practice on the basis of the "one-stop shop" principle;

- improvement of accounting methodology for small business entities;

- improvement of state regulation in the field of accounting.

The process of globalization of the world economy, strengthening the protection of investors' rights and ensuring the transparency of the functioning of international capital markets has led to new approaches to improving the methodology for disclosing economic information about the results of activities of business entities, primarily issuers of securities in international financial markets [19].

Recently, Ukraine has been actively involved in the implementation of International Financial Reporting Standards. This allows accounting to be in line with world standards, and the reporting of Ukrainian enterprises will become clear and comparable to foreign users, which will lead to closer and more active cooperation.

The study and implementation of international standards is necessary for the development of economic relations between Ukraine and foreign countries.

The Law of Ukraine "On Amendments to the Law of Ukraine" On Accounting and Financial Reporting in Ukraine "No. 2164 dated 05.10.2017 broadened the range of enterprises that should apply IFRS during the compilation of financial statements, namely: enterprises that are of public interest, public joint-stock companies, enterprises engaged in mining, enterprises that conduct economic activity by types, the list of which is determined by the $\mathrm{CMU}$, as well as other enterprises that determined the appropriateness of the application of IFRS by will.

It should also be noted that nowadays, in more than 113 countries of the world, public companies are required (or allowed) to prepare financial statements in accordance with international standards.

Experience in applying IFRS in different countries shows that the transition to IFRS is not so painless. Thus, in particular, it is possible to distinguish two spectrum of problems that could become a major obstacle for transition countries to IFRS:

1) legal problems (lack of a body governing the implementation of IFRS; the need for legislative recognition of IFRS; the need for adaptation of national legislation to IFRS; tax orientation of the national accounting system; the absence of an inconsistent detailed guidance on the application of IFRS; the need to introduce effective mechanisms for monitoring compliance with IFRS);

2) the problems of a psychological nature, arising from the introduction and use of international standards by different countries (for example, the difficulty of the application of professional judgments).

The authors of the monograph [20] generalize the problems that arise in the transition of domestic enterprises to IFRS, namely:

1) the absence of a requirement for the mandatory application of IFRS in Ukrainian enterprises;

2) lack of full interpretation and explanations for filling, leading to divergent opinions;

3) lack of skilled personnel with IFRS. It's not just about reporting, but also about its use and understanding;

4) Ukrainian Accounting standards do not reflect all approaches to accounting and valuation models for financial statements, disclosure requirements, and all explanations that are included in international financial reporting standards. For example, there are provisions in IFRS that are absent in Ukrainian standards and vice versa;

5) the need to introduce a new regulatory framework for accounting at the national level;

6) accountants at enterprises ignore standards requirements: reserves are not accrued and future costs and payments are not provided, assets are not deductible and debt is not deducted, deferred tax is not calculated, which leads to data distortion;

7) the desire of Ukrainian accountants to apply financial accounting approaches to tax legislation. This is done to reduce the differences between financial and tax accounting;

8) the emergence of additional costs due to the need to purchase new software, through which reporting would greatly facilitate the work of staff and reduce the possibility of error;

9) the need for additional information required by IFRS and, accordingly, the inclusion of additional 
functions in the duties of the employees of the departments;

10) complexity of individual standards. For example, IFRS standards for the reporting of financial instruments, in particular investments in securities, derivatives, accounts receivable and payables; assets and liabilities should be valued at fair value, which is a difficult task for domestic professionals;

11) preparation of financial statements under IFRS is carried out simultaneously with the keeping of records according to national standards;

12) Ukrainian accountants are used to clear regulation of accounting decisions and procedures, therefore, understanding of IFRS by our country's accountants is associated with some difficulties, for example, the widespread use of professional judgment in recognizing, evaluating and disclosing information in financial statements;

13) the organizational problem. It consists of figuring out who should implement the developed and accepted regulations in the daily practice of an accountant and who should be responsible for the effectiveness of this process. Solving this problem offers a choice of accounting regulation: public or professional. At the same time, this choice depends on the economic situation in the country, the sociopolitical situation, national traditions;

14) the transition to IFRS is also a problem for domestic auditors, as reporting under IFRS requires its further verification and obtaining an audit opinion. Foreign investors do not really trust Ukrainian auditors, so they will appeal to larger global auditing companies, which in turn inevitably increases the cost of the company;

15) IFRS do not regulate reporting by public, budget, charitable or other organizations.

As you know, the transition to IFRS provides new opportunities for both individual economic entities and for the state as a whole. In addressing all of the above problems, business entities have significant benefits from the introduction of IFRS at both macro and micro levels.

Positive aspects of implementation and application of IFRS:

- promote transparency and openness of enterprises. In particular, interested financial report users were able to analyze information about financial and operational risks of enterprises and ways to manage them;

- provide comparability of financial statements of Ukrainian enterprises with similar economic entities abroad, increase investment attractiveness of business entities and expand their access to international financial markets;

- provide investors with the additional information necessary for making investment decisions;

- contribute to improving the quality of the information base for decision-making by management of reporting companies;

- contribute to further convergence of national and international accounting standards.

Conclusions and perspectives of further research. Globalization is the main factor determining the further development of accounting. There are many points of view on the problems of such development, and they are largely associated with globalization. However, at present, the main approach to the development of accounting in the form of International Financial Reporting Standards has been formulated, but the theoretical and methodological bases for the study of processes determined by globalization have not been defined.

Developing the concepts, norms and rules for filing accounting information recognized by many international organizations in financial reporting is a far-sighted step of the economic community of global significance. One of the universal instruments for assessing economic indicators around the world is the reporting, compiled in accordance with international standards. With the help of IFRS, it is possible to provide data on the activities of companies that are understood by the interested user, regardless of his nationality and territorial remoteness from the business entity.

So, at this stage of accounting development for Ukrainian accounting practice, harmonization is the use of IFRS as the basis for creating their own, national standards and a gradual, full transition to IFRS. This approach to accounting is carried out not only in Ukraine but also in other countries of the world.

It should be noted that there are certain problems that our country must resolve before final transition to IFRS. These include: the creation of a coordinating body, reforming education, retraining of accountants, civil servants, users of information, providing state grants to align accounting in individual enterprises and accounting for IFRS, international support, monitoring, adjusting of the process of introducing IFRS. Solving these complex issues will allow reforming accounting in Ukraine and launching a qualitatively new stage in the development of both practice and theory. 


\section{References:}

1. Теперішня фінансова криза загрожує розвалом міжнародної бухгалтерської мови і правил [Електронний ресурс] // Економічна правда. - Режим доступу: https://www.epravda.com.ua/press/2009/02/13/181600/

2. Кузіна Р. В. Корпоративний облік і звітність в Україні: сучасний стан і перспективи розвитку : монографія / Р. В. Кузіна. - Херсон : Грінь Д. С., 2015. - 416 с.

3. Николаева О.Е. Международные стандарты финансовой отчетности : учебное пособие / О. Е. Николаева, Т. В. Шишкова. - М. : Либроком, 2011. - 240 с

4. Голов С.Ф. Бухгалтерський облік в Україні: аналіз стану та перспективи розвитку : монографія / С.Ф. Голов. - К. : МІМ ; Центр учбової літератури, 2007. - 522 с.

5. Нормативно-методичне забезпечення бухгалтерського обліку в умовах застосування міжнародних стандартів фінансової звітності / за ред. Л.Г. Ловінської. - К. : ДННУ «Акад. фін.управління», 2013. - 294 с.

6. Жук В.Н. Основы институциональной теории бухгалтерского учета : [монография] / В.Н. Жук. - К. : Аграрная наука, 2013. -408 с.

7. Пефтиев В. Развивающийся мир: глобализация или регионализация? / В. Пефтиев, В. Черновская // Мировая экономика и международные отношения. - 2000. - № 7. - С. $39-44$.

8. Суржиков М. А.Методологические основы глобализации мировой экономики / М. А. Суржиков // Мировая экономика и международные экономические отношения. - 2012. - № 2. - С. 343 - 347.

9. Елецкий Н.Д. Переход к глобально-информационному способу производства и модификация общей экономической теории / Н. Д. Елецкий // Мировая экономика и международные отношения. - 2008. - № 2. - С. 22 - 29.

10. Фейгин Г. Ф.Развитие национальных экономик в условиях глобализации: историко-экономический аспект // Известия Санкт-Петербургского университета экономики и финансов. - 2009. - № 2. - С. 14 - 24.

11. Принципы бухгалтерского учета / Б. Нидлз, Х. Андерсон, Д. Колдуэлл : пер. с англ. / Под ред. Я. В, Соколова. - 2е изд., стереотип. - М. : Финансы и статистика. 2004. - 496 с.

12. Стефанович Л. И. Глобализация и национальная система бухгалтерского учета / Л. И. Стефанович // Банкаўскі веснік - 2009. - № 25. - С. 17 - 22.

13. Поленова С. Н. Глобализация мировой экономики и тенденции бухгалтерского учета / С. Н. Поленова // Международный бухгалтерский учет. - 2008. - № 8.- С. 7- 17.

14. Панков В. В. Институциональный подход и теория учета / В. В. Панков // Бухгалтерский учет. -2008. - № 1. -С. 51-55.

15. Как развивались стандарты МСФО: немного истории [Электронный ресурс]. - Режим доступа : http://finacademy.net/materials/article/prichinu-pojavlenija-msfo

16. Програма реформування системи бухгалтерського обліку із застосуванням міжнародних стандартів, затверджена постановою Кабінету Міністрів України від 28.10.1998 р. № 1706. [Електронний ресурс]. - Режим доступу : http://zakon2.rada.gov.ua/laws/show/1706-98-п.

17. Про бухгалтерський облік та фінансову звітність в Україні : Закон України від 16.07.1999 р., № 996-XIV [Електронний ресурс] // Відомості Верховної ради України. - Режим доступу : http:// zakon.rada.gov.ua/cgi-bin/laws/main. cgi?nreg=996-14.

18. Стратегія застосування Міжнародних стандартів фінансової звітності в Україні, ухвалена розпорядженням Кабінету Міністрів України від 24.10.2007 p. № 911-р. [Електронний ресурс]. - Режим доступу : http://zakon2.rada.gov.ua/laws/show/911-2007-p.

19. Сопко В. Глобалізаційні процеси та їх вплив на бухгалтерський облік / В. Сопко // Бухгалтерський облік і аудит. 2006. - № 5. - С. $4-10$.

20. Розвиток бухгалтерського обліку в умовах глобалізації та інформатизації суспільства : монографія / О.В. Пальчук, В.М. Савченко, І.В. Рузмайкіна та ін. ; за ред. Г.М. Давидова. - Кропивницький : Ексклюзив-Систем, 2017. - 248 с.

\section{Н. В. Потриваєва, О. І. Лугова, Н. В. Яновська, Ю. О. Клочан. Міжнародні стандарти фінансової звітності як основа розвитку бухгалтерського обліку в умовах гдобадізації} економіки.

у статті висвітлено роль міжнародних стандартів фінансової звітності у процесі глобалізації світової економіки. Представлено аналіз передумов і етапів переходу на міжнародні стандарти фінансової звітності. Охарактеризовано результати застосування міжнародних стандартів звітності, сформульовано їх переваги. Визначено проблеми впровадження міжнародних стандартів фінансової звітності в національну систему обліку України.

Ключові слова: глобалізація економіки, бухгалтерський облік, міжнародні стандарти фінансової звітності, користувачі звітності. 
Н. В. Потриваева, О. И. Луговая, Н. В. Яновская, Ю. А. Клочан. Международные стандарты финансовой отчетности как основа развития бухгалтерского учета в условиях глобализации экономики.

В статье освещена роль международных стандартов финансовой отчетности в процессе глобализации мировой экономики. Представлен анализ предпосылок и этапов перехода на международные стандарты отчетности. Охарактеризованы результаты применения международных стандартов отчетности. Определены проблемы внедрения МСФО в национальную систему учета Украины. Сформулированы преимущества применения международных стандартов финансовой отчетности.

Ключевые слова: глобализация экономики, бухгалтерский учет, международные стандарты финансовой отчетности, пользователи отчетности. 